\title{
The Analysis of Self-Learning Management During the COVID-19 Pandemic Period:
}

\author{
A Study Investigating Students' Perception of Online Learning
}

\author{
Irman Suherman*, Muhammad Fakry Gaffar \\ Universitas Pendidikan Indonesia \\ Bandung, Indonesia \\ *irman.suherman@upi.edu
}

\begin{abstract}
This study aims to analyze the self-learning management of student during online learning in a program developed in Indonesia called school from home during the Covid-19 pandemic. This research used a mix method. Data were collected through surveys and semi-structured interviews with 79 students at private universities. Data analysis used Miles and Huberman's Model of qualitative data, and statistical analysis used for quantitative data. The analysis result found four main themes, namely, learning preparation, learning resources, learning climate, and learning challenges. This research contributes to the literature on online self-learning that have an impact on student success. Broadly, the success of online learning in Higher Education during the COVID-19 Pandemic was determined by technology readiness, learning resources, the learning atmosphere built by students in order to face change and ensure that students do not fall behind.
\end{abstract}

Keywords-COVID-19, higher education, online learning, school from home

\section{INTRODUCTION}

The covid-19 pandemic has been declared a global epidemic, and so far, no way has been found to deal with it. The difficulty of handling the outbreak has made all countries think hard so that the chain of the spread of Covid-19 can be broken. Some of the standards recommended by the World Health Organization [1], such as social distancing, physical distancing and stay at home. In Indonesia, through a speech President Joko Widodo officially announced that on March 2, 2020 there were two Indonesian citizens of infected with Covid-19 [2]. Thus, "large-scale social restrictions" were adopted in various regions. These were followed by other regulations in the form of working from home for workers, and homeschooling for students ranging from the early childhood education level to higher education [3]. This was strengthened by the Ministry of Education and Culture Circular dated March 17, 2020, no. 26962/MPK.A/HK/2020 about Online Learning and Working from Home in the Context of Preventing the Spread of Corona Virus Disease (COVID-19) instruction all university leaders to keep employees, students and lecturers following covid-19 prevention protocols, one of which is to implement online learning from home for students at the same time give lectures at home (Working From Home / WFH) via video conference, digital documents, and other online media.

Remote learning is an alternative in times of lockdown and social distancing due to the COVID-19 pandemic [4]. Remote learning systems certainly change all learning tools and learning strategies carried out by students and lecturers. The student of accustomed with face-to-face learning model in class and did not change his habits, it can be ascertained that the quality of student learning is low. Especially when talking about student learning outcomes during the Covid-19 pandemic, will be largely determined by how students manage online learning independently.

The challenges of online learning are technical constraints related to technology infrastructure and student participation [5]. Seeing this, the mindset changes in learning during the Covid-19 pandemic is very important, so that it will have an impact on changing student learning patterns. Another aspect is learning readiness must to do in remote learning approach. This is where the importance of self-learning management is carried out by students in the context of adapting to new learning habits.

This study aims to analyze self-learning management carried out by students as an effort to adapt to new learning habits during the Covid-19 pandemic. The results of this study are expected to be taken into consideration for lecturers in conducting learning, choose of learning method and strategy and prepare teaching materials to fit the students needs. Another it can also be used as a basis for universities in building learning management to maintain the quality of learning during the Covid-19 pandemic and sustainability of remote learning.

\section{Methodology}

This research used a mix method. Mix method research is research conducted using a research approach that combines or combines qualitative and quantitative [6]. In this research, the 
self-learning management on students was explored in-depth during the COVID-19 Pandemic in higher education.

Participants in this study were 79 students in bachelor's and master's program from private higher education in Bogor. A random sampling technique we used by distributing questionnaires online using Google Form to students in private higher education, namely, Djuanda University and Ibnu Khaldun Universiy. Descriptive data of demographic characteristics, including gender, level of education and scipe of science, are presented in Table 1.

TABLE I. PROFILE OF PARTICIPANTS

\begin{tabular}{|l|l|l|}
\hline & Frequency & $\%$ \\
\hline Gender & & \\
\hline Male & 27 & 34.2 \\
\hline Female & 52 & 65.8 \\
\hline Level of Education & & \\
\hline Bachelor's & 74 & 93.7 \\
\hline Master's & 5 & 6.3 \\
\hline Scope of Science & & \\
\hline Applied Science & 4 & 5.0 \\
\hline Social Science & 48 & 60.8 \\
\hline Education & 27 & 34.2 \\
\hline
\end{tabular}

Data analysis used Miles and Huberman's Model of qualitative data by three main steps, namely data reduction, data display and data verification [7], and statistical analysis used for quantitative data. The Triangulation technique is used to obtain findings and interpretations (interpreting or explaining) data that are more accurate and credible [8]. This technique is used to maintain the credibility of the data obtained.

\section{RESULTS AND DISCUSSION}

As a result of the coding carried out, four categories have been grouped, namely: learning preparation, learning resources, learning atmosphere and the challenges of online learning.

\section{A. Results}

1) Learning preparation: The success of online learning from the institutional side is determined by cloud service resilience, university technological maturity, university organizational readiness and Cloud Based E-Learning imperatives [9]. In addition to the readiness of technology infrastructure, student awareness in using the e-learning system is a determining factor for the success of online learning [10]. The learning preparations for students found in this study to take online learning include technology infrastructure, learning media, supporting facilities and readiness to learn. See table 2 below.
TABlE II. The Students' Perceptions of Learning Preparation DURING THE COVID-19 PANDEMIC

\begin{tabular}{|l|l|l|}
\hline & Frequency & \% \\
\hline Learning Preparation & & \\
\hline Infrastructure of technology & 68 & 86.1 \\
\hline Instructional Media & 2 & 2.5 \\
\hline Supporting facilities & 27 & 34.2 \\
\hline Readiness to learn & 12 & 15.2 \\
\hline
\end{tabular}

In the table 2, describing the highest student perception in online learning preparation during the Covid-19 pandemic is the preparation of technological infrastructure. The students' perceptions in detail are described in table 3 below:

TABLE III. The LEARNING PREPARATION ON LEARNING ONLINE BY STUDENT'S IN SCHOOL FROM HOME (SFH)

\begin{tabular}{|c|c|c|c|c|}
\hline Categories & $\begin{array}{c}\text { Infrastruc } \\
\text { ture of } \\
\text { technology }\end{array}$ & $\begin{array}{l}\text { Instructio } \\
\text { nal Media }\end{array}$ & $\begin{array}{c}\text { Supporting } \\
\text { facilities }\end{array}$ & $\begin{array}{c}\text { Readiness } \\
\text { to learn }\end{array}$ \\
\hline \multirow{4}{*}{$\begin{array}{l}\text { Learning } \\
\text { Preparation }\end{array}$} & $\begin{array}{l}\text { Laptop } \\
\text { Mobile } \\
\text { phone }\end{array}$ & $\begin{array}{l}\text { Zoom } \\
\text { WhatApps }\end{array}$ & $\begin{array}{l}\text { Notebooks } \\
\& \\
\text { stationary }\end{array}$ & $\begin{array}{l}\text { Students } \\
\text { spirit } \\
\text { Mentality } \\
\end{array}$ \\
\hline & $\begin{array}{l}\text { Quota } \\
\text { Internet } \\
\text { Signal }\end{array}$ & LMS & $\begin{array}{l}\text { Reference } \\
\text { Books } \\
\text { (printed) }\end{array}$ & $\begin{array}{l}\text { Healthy } \\
\text { body } \\
\text { Additional } \\
\text { time }\end{array}$ \\
\hline & & & $\begin{array}{l}\text { subject } \\
\text { matter from } \\
\text { lecturers }\end{array}$ & $\begin{array}{l}\text { Reading a } \\
\text { subject } \\
\text { matter }\end{array}$ \\
\hline & & & & $\begin{array}{l}\text { Learning } \\
\text { environme } \\
\text { nt }\end{array}$ \\
\hline
\end{tabular}

Technological infrastructure in the form of laptops and mobile phones as the main tools used in online learning, cannot be separated from quota and internet signal. Several students gave this opinion:

Preparation of quota, internet signal, stationery, mobile phone and laptops. (Student 9)

Preparation for online learning includes quota and supporting tools such as mobile phone and laptops. (Student 14)

Learning media used in online learning are zoom applications, whatApps and Learning Management System (LMS). This application is commonly used by lecturers to share subject matter and media for questions and answers (Q\&A) related to the topics being discussed. Related to that, student 10 said:

Maybe it's like preparing a zoom application because some lecturers use this application and whatApps to share information about course assignments. (Student 10)

To support the smooth running of online learning, students also need to prepare books and stationery, printed references and subject matter. This is useful for increasing understanding when online learning (synchronous). Notebooks are useful for recording basic things related to the course material being 
studied. However, another the preparation of learning facilities, students' physical and psychological readiness in the form of spirit, mentality, physical health is more important. Students also need to increase their study time outside of synchronous learning, read subject matter first, and prepare a conducive learning environment at home. Related about this several students said:

The first thing that is prepared is mental, because often laziness to take part in online learning appears suddenly, sometimes even the motivation decreases. (Student 79)

During online learning I have to prepare everything, especially the readiness of the brain, which has to work harder to understand the material. (Student 51)

2) Learning resources: The successful achievement of online learning outcomes in the School From Home (SFH) will depend on the learning resources available and used by students. Relying on lecture material provided by lecturers will not be enough to support learning with the remote learning system. The students must be willing to find other learning resources, especially IT-based learning resources that they can get without leaving home. Utilization of ICT as a major media and learning resource is more dominant than learning resources from lecturers [11]. Learning resources such as e-books, online journals, material from YouTube, learning materials from lecturers, material from Google are learning resources that are often used by students in online learning. Another that, printed books are still used by students as a learning resource. See table 4 below:

TABLE IV. LEARNING RESOURCES ON ONLINE LEARNING DURING THE COVID-19 PANDEMIC

\begin{tabular}{|l|l|l|}
\hline & Frequency & \% \\
\hline Learning Resources & & \\
\hline E-Book & 9 & 11.4 \\
\hline Journal Online & 6 & 7.6 \\
\hline Soruces from YouTube & 7 & 8.9 \\
\hline Sources from Lecturer & 21 & 26.6 \\
\hline Sources from Google & 55 & 69.6 \\
\hline Book of references (printed) & 35 & 44.3 \\
\hline
\end{tabular}

The limited access to printed books on online learning during the Covid-19 pandemic has an impact on changes in the use of learning resources based on IT-based learning resources. Student 63 and 31 explained this:

The Internet based learning resources most of used on Online Learning during the Covid-19 pandemic. (Student 63)

I used the learning resources on online learning usually come from academia.edu, on this website there are lots of materials or e-books that can be studied according to the course. (Student 31)
3) Learning atmosphere: The main thing that is influenced by the change in the face-to-face learning system in the classroom to the online learning system is the learning atmosphere. Online learning provides a new atmosphere for students, where student involvement in online learning is the main thing so that learning is more meaningful. The learning atmosphere obtained in online learning during the Covid-19 pandemic, several students commented on this:

The online learning makes me nervous, because there are many materials that I have to master myself, the explanation of the material from the lecturer is limited, it is difficult to interact directly which causes awkwardness to ask about the material being explained. (Student 79)

I boring when online learning and the material is difficult to understand if I don't meet face to face with the lecturer. (Student 64)

I feel on learning during the pandemic period is boring, because every day we should be able to interact directly with friends and lecturers, but currently only studying at home. (Student 31)

Difficulty to understanding material is a major students problem in online learning. Meanwhile, the boring learning atmosphere becomes a challenge for lecturers, how lecturers should be able to create a more enjoyable and interesting learning atmosphere. Another that, there are several student opinions as a new and fun learning atmosphere. So, the student feeled to difference of learning atmosphere can be divided into two categories, namely negative atmosphere (boring and many trouble) and positive atmosphere (new and fun atmosphere). Students 23 and 63 commented on this:

\section{Online learning for me is a new atmosphere. (Student 23)}

We must be truly independent online learning, because if we only rely on material from lecturers or discussions, there is little chance that we will master the material. (Student 63)

The atmosphere of online learning during the Covid-19 pandemic can be illustrated in Figure 1 below:

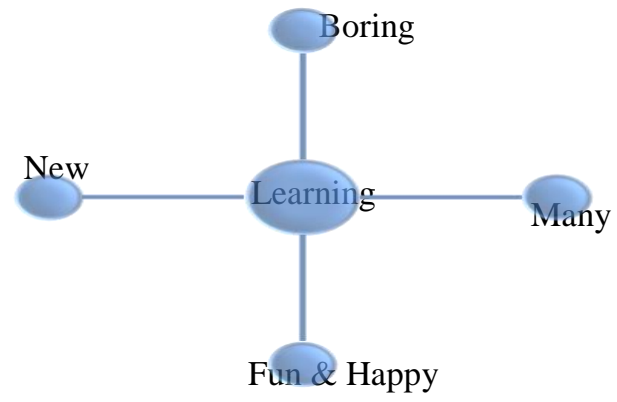

Fig. 1. The Learning atmosphere of online learning. 
TABLE V. THE STUDENTS' PERCEPTIONS OF THE ATMOSPHERE OF ONLINE LEARNING DURING THE COVID-19 PANDEMIC

\begin{tabular}{|l|l|l|}
\hline & Frequency & \% \\
\hline Learning Atmosphere & & \\
\hline Boring & 45 & 57.0 \\
\hline Many trouble & 21 & 26.6 \\
\hline Fun \& Happy & 9 & 11.4 \\
\hline New atmosphere & 4 & 5.0 \\
\hline
\end{tabular}

The boring atmosphere still dominates the atmosphere felt by students in online learning during the Covid-19 pandemic. There are many factors why this happens, but it needs to be a concern for lecturers and institutions in implementing online learning. Especially if this learning system is a 21 st century learning models.

4) The challenges of online learning: The challenges faced by students in online learning during SFH include four subthemes, namely technical berriers, time conditioning, scheme of online learning, and internal student's. Figure 2 below illustrates the challenges faced by students.

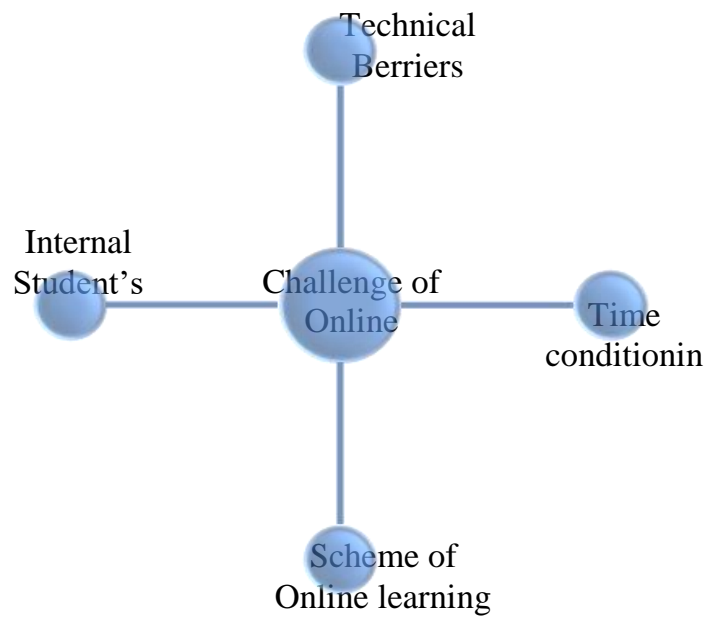

Fig. 2. The challenges of online learning

The challenges related technical berriers of student face is not all students have laptops, mobile phones, quotas and internet signal that suit their needs. These constraints can student participation in learning is not optimal.

Another challenge is conditioning the learning time. Online learning has two types namely synchronous and unsynchronous, therefore students need to manage time to follow the learning patterns in the online learning system. This allows students learning of meaningful.

The challenges of learning are internet signal and quotas, especially in remote areas like me. Often times there are problems with blackouts so that the signal suddenly disappears. (Student 63)
Internet connection is unstable, demands to understand the material itself, assignments that must be sent in the form of files, but conditions are not possible to do so. (Student 27)

The changing the learning scheme is also a challenge in itself where students are required to change the mindset in online learning, namely students are responsible for their learning, explanations from lecturers are not enough and student-centered learning [12].

Another challenge is how students control themselves to remain spirit, enthusiastic, even honest in doing assignments and take responsibility for their own learning. The challenge of restraining laziness and creating a good learning atmosphere in order to increase learning motivation is very important. Several student opinions:

The challenge for me is honesty. In my opinion, when learning online, students can make answers to recovery tasks by copying from the internet. This honesty is a challenge for me. (Student 1)

The challenge is that even though I'm bad mood, I still have to study, and online learning at home makes me must more independently and search for my own course material. (Student 31)

The challenges faced by students will affect the online learning process. All technical berriers and internal student will have an impact on the learning quality. Changing the student mindset is also an important thing to do so that they are able to adaptive of online learning.

\section{B. Discussion}

The online learning has been implemented during the Covid-19 epidemic, it has even become a learning strategy implemented in various countries, such as Australia, Egypt, China, Germany, Hong Kong and other countries including Indonesia [13]. Changes of learning system have an impact on lecturers as well as students and universities as learning managers. In Indonesia, This includes changes in learning strategies, technological readiness for lecturers in implementing online learning, support and motivation of lecturers, parents, universities, and government involvement [5].

The impact of online learning carried out at home has had an influence on the quality of learning. In this study, students believe that the availability of technology infrastructure such as laptops, mobile phones, quotas, internet signal, IT-based learning resources and a learning atmosphere needs to be built so that learning continues to run well. It also becomes a challenge for students, lecturers and universities in supporting online learning. Even the readiness of technology infrastructure, student awareness in using the e-learning system is a determining factor for the success of online learning [10].

Students must provide technology infrastructure, learning media, books and writing tools as well as motivation and mentality before learning. This learning preparation will be 
very important as a support for the smooth learning process. Especially technology infrastructure, will greatly determine the sustainability of online learning. But, this is still a berriers faced by students, the providing the software and hardware requires money. The most significant berriers students face while studying at home is the lack of internet access and electronic devices [14].

Support from higher education institutions and the government is needed in the problem of providing adequate technology infrastructure during online learning. Especially for students affected by the Covid-19 pandemic from the economic sector, provision of technological infrastructure will be increasingly difficult. If the technology infrastructure not provided, so accessing learning on online system becomes impossible. If this happens, online learning is a solution to increasing the expansion and distribution of access to quality and relevant education as needed [11] cannot be achieved.

In addition, students need to use IT-based learning resources. Current conventional learning resources are not enough, especially since students' access to libraries and finding reading material in bookstores is currently very limited. WHO recommends maintaining social distancing and physical distancing and stay at home as a way to stop the spread of Covid-19, making students unable to access learning resources such as books, journals, newspapers and other learning resources printed available in the library [1].

So, the student's must be improved self-learning management in order to adaptive to changes in the current learning system. School from home implies that learning activities are fully the responsibility of students, the explanation and material provided by the lecturer is not the main thing so that students are required to be able to learn independently, student-centered learning. Lecturers are no be a center of knowledge, no opinios "tanpa saya, mahasiswa tidak bisa apa-apa" [12]. This is an old mindset that seems to shackle learning so far.

\section{CONCLUSION}

School from home during the Covid-19 pandemic has had a significant impact on learning systems in the world. More policies and strategies have been doing by countries in dealing with this pandemic. The IT-based remote learning system is a solution learning sustainability future even universities are closed. However, the self-learning management of student is very important so that online learning remains of high quality. Readiness of technology infrastructure (laptops, mobile phones, quota, internet signal), learning media, books and writing tools, students' spirit and mentality and learning atmosphere (environment) must always be before learning is doing. Although everyone's hope is that things return to normal, however, the students must be self-learning management so that they are accustomed to facing change and to ensure that students do not fall behind. Students must change mindset about learning, that the learning process is own responsibility. In this case, the lecturer acts a facilitator, and the university must be able to provide facilities and infrastructure to support online learning.

\section{REFERENCES}

[1] World Health OrganiZation. Coronavirus disease (COVID-19) advice for the public., from https://www.who.int/emergencies/diseases/novel-coronavirus2019/advice-for-public Retrieved September 22, 2020.

[2] B. Bima, Rangkaian Peristiwa Pertama Covid-19. from Rangkaian Peristiwa Pertama Covid-19: www.kompas.id. Accessed April 18, 2020.

[3] Kemendikbud. Surat Edaran tentang Pembelajaran Daring dan Bekerja dari Rumah dalam Rangka Pencegahah Penyebaran Corona Virus Disease (COVID-19). Jakarta: Kemendikbud. 2020.

[4] A. Wahab, "Online and Remote Learning in Higher Education Institutes A Necessity in light of COVID-19 Pandemic". Higher Education Studies, Vol. 10, No. 3, 16-25. 2020

[5] Rasmitadila, R.R. Aliyyah, R. Rahmadtullah, A. Samsudin, E. Syaodih, M. Nurtanto, et al., "The Perceptions of Primary School Teachers of Online Learning during the COVID-19 Pandemic Period: A Case Study in Indonesia”. Journal of Ethnic and Cultural Studies, 202, 90-109.

[6] J.W. Creswell, Research Design: Qualitative, Quantitative, and Mixed Methods Approaches, Third Edition. California: SAGE Publication Inc. 2009.

[7] M.B. Miles and A.M. Huberman, Qualitative Data Analysis, Second Edition. London: Sage Publication. 1994.

[8] Sugiyono, Metode Penelitian Pendidikan (Pendekatan Kuantitatif, Kualitatif dan R\&D). Bandung: Alfabeta. 2015.

[9] Q.N. Naveed and N. Ahmad, "Critical Success Factors (CSFs) for Cloud-Based e-Learning". International Journal of Emerging Technologies in Learning, Vol. 14, No. 1, 140-149. 2019.

[10] A.Y. Alqahtani and A.A. Rajkhan, "E-Learning Critical Success Factors during the COVID-19 Pandemic: A Comprehensive Analysis of ELearning Managerial Perspective". Education Science, Vol. 10, Issue 9 , 1-16. 2020.

[11] Kemendikbud. UU No. 24 tahun 2012 tentang Penyelenggaraan Pendidikan Jarak Jauh pada Pendidikan Tinggi. Jakarta: Kemendikbud RI.

[12] F. Jalal, Pendidikan Tinggi Indonesia Pasca Covid-19: Bagaimana nasibnya? (2020, May 15)

[13] J. Crawford, K.B. Henderson, J. Rudolph, B. Malkawi, M. Glowatz, R Burton, et al., COVID-19: 20 countries' higher education intra-period digital pedagogy responses. Journal of Applied Learning \& Teaching, Vol. 3 No. 1, 9-28. 2020.

[14] D. Sikrit, Learning from home during the COVID-19 pandemic Retrieved September 24, 2020, from Unicef Indonesia: https://www.unicef.org/indonesia/coronavirus/stories/learning-homeduring-covid-19-pandemic. Accessed June 2, 2020. 